\title{
再生ポーラスアスファルト混合物 の諸性状と配合設計に関する検討
}

\author{
新田弘之 $^{1} \cdot$ 西崎到 $^{2} \cdot$ 小長井彰祐 ${ }^{3} \cdot$ 伊藤正秀 $^{3}$ \\ ${ }^{1}$ 正会員 工修 独立行政法人土木研究所 材料地盤研究グループ（テ305-8516 茨城県つくば市南原 1-6） \\ ${ }^{2}$ 正会員 博 (工) 独立行政法人土木研究所 材料地盤研究グループ（テ305-8516 茨城県つくば市南原 1-6） \\ 3 工修 独立行政法人士木研究所 基礎道路技術研究グループ（テ305-8516 茨城県つくば市南原 1-6） \\ ${ }^{4}$ 正会員 独立行政法人土木研究所 基礎道路技術研究グループ（テ305-8516 茨城県つくば市南原 1-6）
}

\begin{abstract}
ポーラスアスファルト混合物の再生手法を確立することを目的に, 現在検討されているアスファルトの抽 出回収を行わずに主にカンタブロ損失率を指標として行う配合設計法により再生ポーラスアスファルト混 合物を作製し, 再生混合物の諸性状を調査するとともに, 配合設計法の改善策について検討した. その結果, 配合設計時であまり検討されなかったカンタブロ損失率以外の性状については, 満足な性状が得られない場 合があることも分かった. さらに, 配合設計法の改善策について検討した結果, 比較的簡便に行える試験を 追加することにより，耐久性を考慮した配合設計が行える可能性があることが分かった.
\end{abstract}

Key Words : porous asphalt mixture, recycled mixture, modified asphalt, mix design

\section{1. はじめに}

排水性舗装は, 平成 8 年の「排水性舗装技術指針 (案)」 ((社)日本道路協会) 発刊以来, 施工量が増大しており, これに伴い施工ストックも年々増大している.一部の排 水性舗装は，更新の時期を迎えており，今後排水性舖装 由来の舗装発生材の増大が見込まれる. 舗装の更新にあ たっては舗装発生材の再生利用が不可欠であるが，改質 アスファルトの抽出回収に課題があることや再生混合時 のバインダ性状の回復程度が十分に把握できないことな ど ${ }^{1)}$ から, 排水性舗装の再生利用については技術が確立し ていない. 平成 16 年刊行の「舗装再生便覧」((社)日本道 路協会）においても，排水性舗装の再生については，付 録として検討事例が紹介されているだけである.このた め, 排水性舗装の再生利用技術の早期の確立が求められ ている.

「舖装再生便覽」にも紹介された本松らによる検討事 例 ${ }^{2)}$ では, 発生材からの旧アスファルトの抽出回収を行わ ず，主にカンタブロ損失率を指標として配合設計を行う 方法が提案されている. 配合設計法としては非常に簡便 である一方, カンタブロ損失率では表せない混合物性状 の程度は不明である。 そこで, 本検討では，この「舗装 再生便覧」付録に紹介された配合設計法で設計した再生 ポーラスアスファルト混合物を用いて混合物性状の検討 を行った. その結果, 一部の配合では, 新規混合物より
性状が劣るものがあり，耐久性の高い再生ポーラスアス ファルト混合物の配合設計を行うには, カンタブロ試験 以外の評価試験の追加も必要と考えられたので報告する.

\section{2. 方法}

\section{（1）配合設計方法}

「舗装再生便覧」に紹介された配合設計方法は, 使用 する材料 (再生用添加剤, 再生用高粘度改質アスファル 卜）により異なる. 再生用添加剂を用いる配合設計 A（図 -1）では，再生用添加剤の添加量を決定する工程がある が，再生用高粘度アスファルトを用いる配合設計 B (図 -2）では，その工程はなく，また最適アスファルト量の 決定方法も通常と異なり, カンタブロ試験を用いたもの になっている. 本研究では, これら 2 つ方法により, 再生ポーラスアスファルト混合物を作製することにした.

本研究で行った配合の概要を表-1 に示寸. 配合設計 A は再生用添加剂を用いて再生骨材の配合割合は $30,50 \%$ とした. また配合設計 B は再生用高粘度改質アスファル 卜を用いて，再生骨材の配合割合は $50 \%$ とした。 なお， 配合設計 C は比較のための新規骨材での配合設計であり, 再生骨材の配合割合 $0 \%$ と表示した.

\section{（2）使用材料}

再生骨材は, 新潟県内の一般国道で 8 年間供用した排 


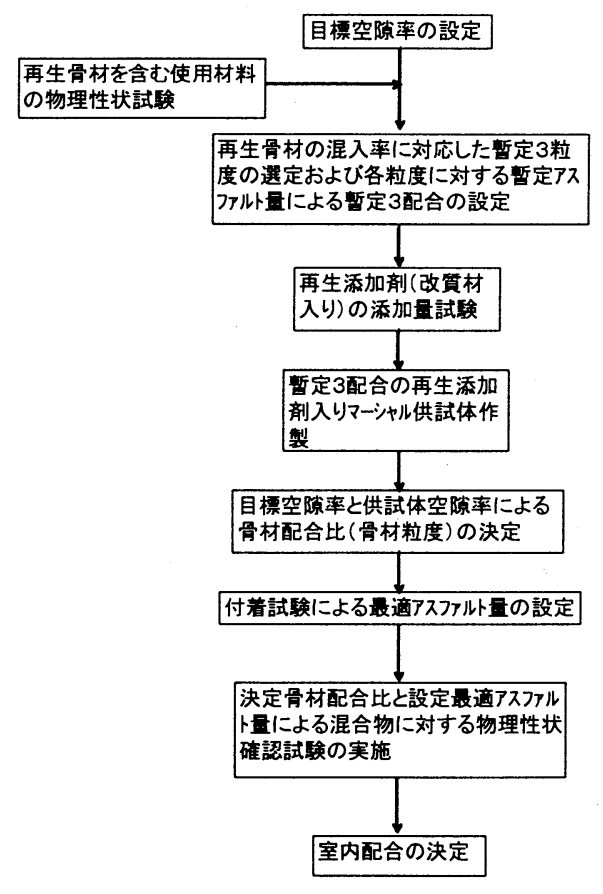

図-1 配合設計 $\mathrm{A}$ の流れ

(戥装再生便覧に紹介された方法を基に作成)

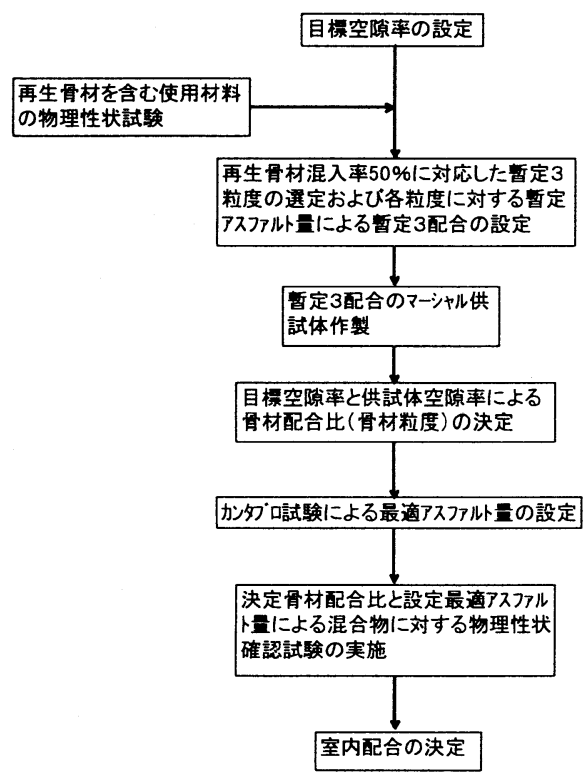

図-2 配合設計 B の流れ

(舗装再生便覧に紹介された方法を基に作成)

表-1 再生混合物および新規混合物の配合設計法の概要

\begin{tabular}{|c|c|c|}
\hline & $\begin{array}{l}\text { 再生骨材 } \\
\text { 配合割合 } \\
\end{array}$ & 概 要 \\
\hline 配合設計 A & $\begin{array}{l}30 \% \\
50 \%\end{array}$ & $\begin{array}{l}\text { 再生用添加剤を用いた再生。 } \\
\text { 再生用添加剤の添加量を変えてカンタブロ } \\
\text { 試験を行い カンンタブロ損失率が } 15 \% \text { } 15 \% \\
\text { なるよう添加量を決定。 } \\
\text { ダレ圾験によりアスファルト量を決定。 }\end{array}$ \\
\hline 配合設計 B & $50 \%$ & $\begin{array}{l}\text { 再生用改質アスファルトを用いた再生。 } \\
\text { アスファル量を変えてカンタブロ試験を } \\
\text { 行い、カンタブロ損失率の変曲点からアスフ } \\
\text { アルト量を決定 (変曲点のアス量+ } 0.2 \%) 。\end{array}$ \\
\hline 配合設計 C & $0 \%$ & 新規。 (排水性舗装技術指針 (案)） \\
\hline
\end{tabular}

表-2 再生骨材の性状

\begin{tabular}{|c|c|c|c|}
\hline \multicolumn{2}{|c|}{ 項目 } & $\begin{array}{c}\text { 抽出前再生骨材 } \\
(13-5 \mathrm{~mm})\end{array}$ & $\begin{array}{c}\text { 抽出後再生骨材 } \\
(13-5 \mathrm{~mm})\end{array}$ \\
\hline \multirow{3}{*}{$\begin{array}{l}\text { 通 } \\
\text { 過 }\end{array}$} & 13.2 & 100 & 100 \\
\hline & 9.5 & 79.2 & 85.4 \\
\hline & 4.75 & 7.5 & 21.4 \\
\hline \multirow{2}{*}{$\begin{array}{l}\text { 重 } \\
\text { 量 }\end{array}$} & 2.36 & - & 16.5 \\
\hline & 0.6 & - & 13.1 \\
\hline \multirow{3}{*}{$\begin{array}{l}\text { 百 } \\
\text { 分 } \\
\text { 率 }\end{array}$} & 0.3 & - & 8.9 \\
\hline & 0.15 & - & 5.1 \\
\hline & 0.075 & - & 3.3 \\
\hline \multicolumn{2}{|c|}{ アスフアル量\% } & - & 4.57 \\
\hline
\end{tabular}

表-3 回収アスファル の主な性状

\begin{tabular}{|c|c|c|}
\hline \multicolumn{2}{|c|}{ 針入度 $1 / 10 \mathrm{~mm}$} & 17 \\
\hline \multicolumn{2}{|c|}{ 軟化点 ${ }^{\circ} \mathrm{C}$} & 66.9 \\
\hline \multirow{2}{*}{$\begin{array}{l}\text { 伸度 } \\
\mathrm{cm}\end{array}$} & $15^{\circ} \mathrm{C}$ & 47.0 \\
\hline & $5^{\circ} \mathrm{C}$ & 0.5 \\
\hline \multicolumn{3}{|c|}{$\begin{array}{l}\text { 表-4 高粘度改質 } \\
\text { アスファルの主な性状 }\end{array}$} \\
\hline \multicolumn{2}{|c|}{ 針入度 $1 / 10 \mathrm{~mm}$} & 67 \\
\hline \multicolumn{2}{|c|}{ 軟化点 ${ }^{\circ} \mathrm{C}$} & 94 \\
\hline \multirow{2}{*}{$\begin{array}{l}\text { 伸度 } \\
\mathrm{cm}\end{array}$} & $15^{\circ} \mathrm{C}$ & $100+$ \\
\hline & $4^{\circ} \mathrm{C}$ & 70 \\
\hline
\end{tabular}

表-5 使用した再生用材料

\begin{tabular}{c|c|c}
\hline 試験項目 & 再生用添加剤 & 再生用改質久イファ忆 \\
\hline 針入度 $(1 / 10 \mathrm{~mm})$ & - & 91 \\
\hline 軟化点 $\left({ }^{\circ} \mathrm{C}\right)$ & - & 95.5 \\
\hline 密度 $\left(\mathrm{g} / \mathrm{m}^{3}\right)$ & 0.951 & 1.025 \\
\hline $60^{\circ} \mathrm{C}$ 粘度 $\times 10^{4} \mathrm{~Pa} \cdot \mathrm{s}$ & 67.5 & $10+$ \\
\hline
\end{tabular}

表-6 実施した主な試験

\begin{tabular}{|c|c|c|c|}
\hline & 試験項目 & 評価値 & 試験の概要 \\
\hline \multirow{4}{*}{$\begin{array}{l}\text { 混 } \\
\text { 合 } \\
\text { 物 } \\
\text { 試 } \\
\text { 験 }\end{array}$} & $\begin{array}{l}\text { カンタブロ } \\
\text { 訊験 }\end{array}$ & $\begin{array}{l}\text { カンタブロ } \\
\text { 損失量 }\end{array}$ & $\begin{array}{l}\text { 舗装圾験法便覧別冊 1-1-2Tによる. } \\
\text { 圾験温度 } 20, \quad-20^{\circ} \mathrm{C}\end{array}$ \\
\hline & 圧裂試験 & $\begin{array}{l}\text { 圧裂強度 } \\
\text { 圧裂変位量 }\end{array}$ & $\begin{array}{l}\text { 舗装圾験法便覧 3-7-6による. } \\
\text { 圾験温度－10,0,5,10,15,20,600 }\end{array}$ \\
\hline & $\begin{array}{c}\text { トラバース } \\
\text { 走行ホイール } \\
\text { トラッキング } \\
\text { 圾験 }\end{array}$ & 透水量 & $\begin{array}{l}\text { ホイールトラッキング試験機を用 } \\
\text { いて, 走行位置を左右にずらしなが } \\
\text { ら載荷. 荷重 } 686 \mathrm{~N} \text {, 走行速度 } 42 \\
\text { 回 } / \mathrm{min}, \text { 走行距離 } 230 \mathrm{~mm}, \quad \text { トバ } \\
\text { ース速度 } 100 \mathrm{~mm}, \text { トラバース幅 } \\
250 \mathrm{~mm}\end{array}$ \\
\hline & 据え切り圾験 & $\begin{array}{c}\text { 沈下量 } \\
10 \mathrm{~mm} \text { に達 } \\
\text { するまでの } \\
\text { 走行回数 }\end{array}$ & $\begin{array}{l}\text { ホイールトラッキング供試体上に } \\
\text { おいて, 半径 } 100 \mathrm{~mm} \text { の円周でタイ } \\
\text { ヤ走行. 荷重 } 686 \mathrm{~N} \text {, 走行回転数 } 42 \\
\text { 回 } / \mathrm{min}, \text { 走行時間 } 120 \mathrm{~min}, \text { 試験温 } \\
\text { 度 } 60^{\circ} \mathrm{C}\end{array}$ \\
\hline \multirow{3}{*}{$\begin{array}{l}\text { バ } \\
\text { イ } \\
\text { ン } \\
\text { ダ } \\
\text { 試 } \\
\text { 験 }\end{array}$} & $\begin{array}{l}\text { アスファルト } \\
\text { の回収試験 }\end{array}$ & - & 舖装試験法便覽 3-9-7 による. \\
\hline & 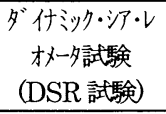 & $\begin{array}{l}\text { 複素弾性率 } \\
\text { 位相角など }\end{array}$ & 舗装試験法便覧別冊による. \\
\hline & 伸度試験 & 伸度 & $\begin{array}{l}\text { 試験法便覧 3-5-3 による. } \\
\text { 試験温度 } 4^{\circ} \mathrm{C}\end{array}$ \\
\hline
\end{tabular}

水性舗装からの切削材をもとに調整したものである 13〜 5mmの粒径に調整した後の再生骨材の一般性状を 表-2に示す.

再生骨材から回収したアスファルトの性状を表-3に 示す．針入度は 20 以下に低下しており，また軟化点も 新規の高粘度改質アスファルトと比べて低下している. また，新規アスファルトとして使用した高粘度改質ア スファルトの性状を表 4 に示す.このアスファルトは, 切削材に含まれる高粘度改質アスファルトと同じ製造 メーカのもので，寒冷地用に低温性状の改善が図られ たものである. さらに，再生に使用した再生用添加剂 および再生用改質アスファルトには表-5に示すものを 用いた. 


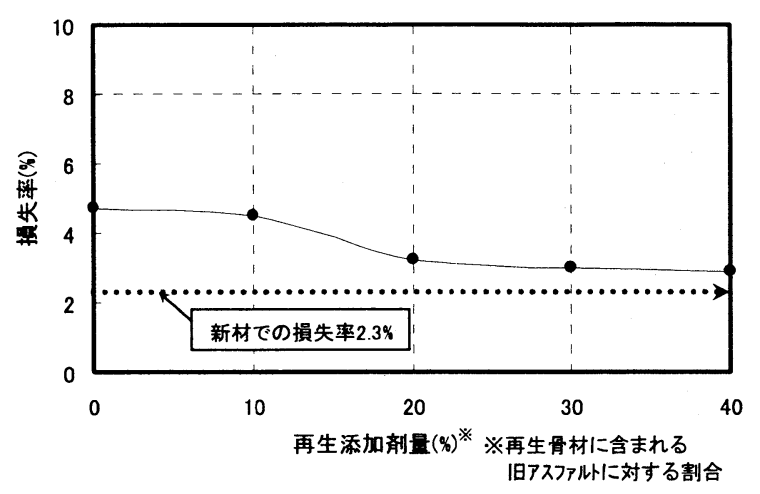

図-3 カンタブロ試験による再生用添加剤の添加量の検討 (配合設計 $\mathrm{A}<30 \%>$, 試験温度 $20^{\circ} \mathrm{C}$ )

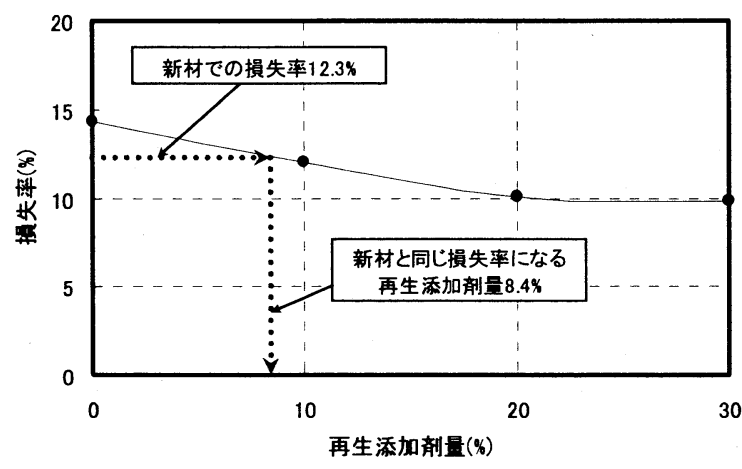

図-4 カンタブロ試験による再生用添加剤の添加量の検討 (配合設計 $\mathrm{A}<30 \%>$ ，試験温度 $-20^{\circ} \mathrm{C}$ )

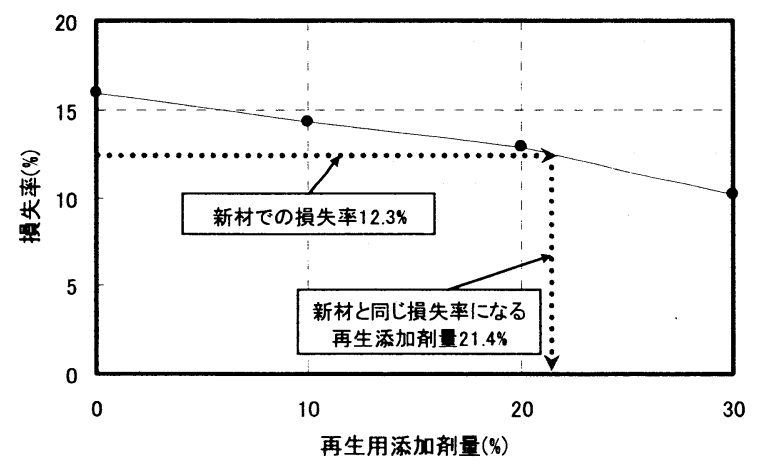

図-5 カンタブロ試験による再生用添加剤の添加量の検討 (配合設計 $\mathrm{A}<50 \%>$ ，試験温度 $-20^{\circ} \mathrm{C}$ )

\section{（3）試験方法}

実施した試験の方法を表-6 に示す.ここで，トラバー ス走行ホイールトラッキング試験は，ホイールトラッキ ング試験の条件に加え, タイヤの走行位置を左右に少し ずつ変えながら走行させ，その振り幅をトラバース幅， 横方向の移動速度をトラバース速度とした．また，据え 切り試験は，供試体上でタイヤを円形に走行させ，骨材 の移動による沈下量を計測した.

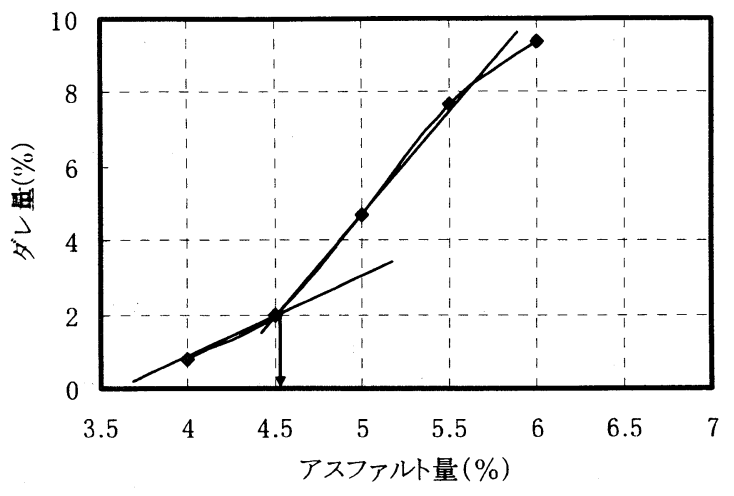

図-6 付着試験の結果

(配合設計 $\mathrm{A}<30 \%>$ )

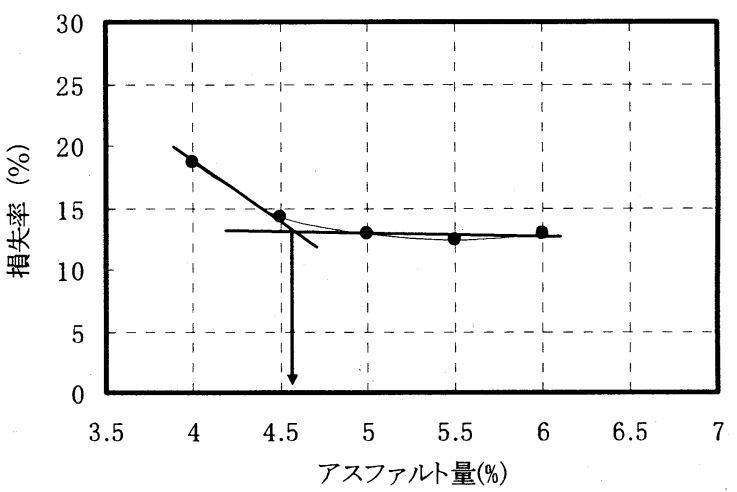

図-7 カンタブロ試験の結果

(配合設計 $\mathrm{A}<30 \%>$ ，試験温度 $-20^{\circ} \mathrm{C}$ )

\section{3. 配合設計の結果}

(1) 配合設計 A

a) 再生用添加剂の添加量の決定

配合設計 A では，まず再生用添加剤の添加量を求める ため, 添加量を変化させてカンタブロ試験を実施した. 再生骨材の配合割合が $30 \%$ 時の結果を図-3 に示す. $20^{\circ} \mathrm{C}$ でカンタブロ試験を実施したところ目標值である $15 \%$ には配合割合 $0 \%$ ですでに下回っており，新材と同程 度のカンタブロ損失率になる添加量を求めることができ なかった，そこで，新規混合物のカンタブロ損失率を目 標值にしたが，新規混合物（配合設計 C）のカンタブロ 損失率は $2.3 \%$ であったため，これでも新規混合物と同程 度のカンタブロ損失率にするための添加量が求めること はできなかった：この原因として，新アスファルトに寒 冷地用に低温性状の改善が図られたものを使用したため, $20^{\circ} \mathrm{C}$ でのカンタブロ損失率が低く，これを使用しただけ で，カンタブロ損失率が低くなるためと考えられた.

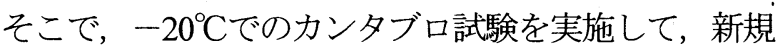
混合物と同程度の損失率を目標として配合設計を試みた。 低温でのカンタブロ試験による再生用添加剤量の検討結 果を図-4，5に示す．新規混合物（配合設計 C) の損失率 


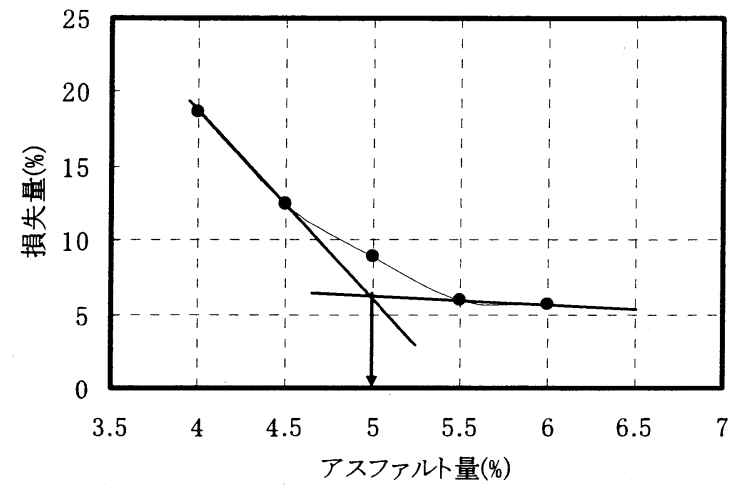

図-8 カンタブロ試験の結果

(配合設計 $\mathrm{B}<50 \%>$, 試験温度 $20^{\circ} \mathrm{C}$ )

12.3\%を目標にしたところ, 添加量を求めることができた.

\section{b) アスファルト量の決定}

アスファルト量を決定するため, 付着試験を行った. 結果を図-6に示す。この結果, 変曲点は $4.6 \%$ となり, 通 常のポーラスアスファルト混合物では 5\%付近の值をと ることが多いが，それと比べて若干小さい值になった. アスファルト量が不十分な場合，骨材飛散抵抗性の低下 など耐久性への影響が懸念されるため，カンタブロ試験 を実施し，最小アスファルト量を求めた．結果を図-7に 示す．最小アスファルト量は $4.7 \%$ となり，付着試験から 求めた值を上回った．通常のポーラスアスファルトの配 合設計では，カンタブロ試験から求まる変曲点を最小ア スファルト量とし, 付着試験から求めた変曲点を最大ア スファルト量として，両者の間の值をア スファルト量に設定できるが，最大アス ファルト量と最小アスファルト量の数 值が逆転してしまったため，付着試験の 結果が採用できながた。これは，配合 割合 $50 \%$ の場合でも同様の傾向であっ た. 最小アスファルトを下回る值をアス ファルト量として設定することは，耐久 性を大きく損なう可能性があったため,

「舗装再生便覧」に紹介された方 法を参考に, 配合設計 B で提案さ れている, カンタブロ試験から求 めた変曲点 $+0.2 \%$ を最適アスフ アルト量とする方法を採用した。 それぞれの結果を表-7に示す。

\section{(2) 配合設計B}

配合設計 B では, 再生用添加剂 と改質材がプレミックスされた 再生用改質アスファルトを用い るため, アスファルトに関する操
作は，最適アスファルト量の設定のみであり，設定方法 はカンタブロ試験から求めた変曲点 $+0.2 \%$ の添加量とす るものである. カンタブロ試験の結果を図-8に示す，そ の結果，最適アスファルト量は $5.2 \%$ となった。配合設計 A，C の結果と合わせて，表-7 に示す．なお，最適アス ファルト量における新アスファルトと旧アスファルトお よび再生用添加剤の内訳も合わせて示寸.

\section{4. 再生ポーラスアスファルト混合物}

\section{および再生バインダの性状}

\section{（1）混合物性状}

3. で配合設計した再生ポーラスアスファルト混合物 について各種性状試験を行った. 主な性状を表8に示す. 配合設計 A では， $-20^{\circ} \mathrm{C}$ のンタブロ損失率を配合設計 C に合わせる形で配合設計を行ったので，同程度の值を 示したが，配合設計 B では特にカンタブロ損失率の大小 に注目して配合設計を行っていないため, 配合設計 C と は異なる傾向を示した．動的安定度は，いずれも 3,000 回 $/ \mathrm{mm}$ 以上となったが，配合割合 $50 \%$ のものはその中で は小さい值を示した．据え切り試験でも，再生骨材の配 合割合が $50 \%$ のものは小さい值を示し，特に配合設計 B の值が小さくなっており，骨材飛散抵抗性が低い可能性 があることが分かった.

以上より, 現在検討されている再生ポーラスアスファ ルト混合物の配合設計法に従って配合した場合，新規混 合物と異なる性状がいくつか見られた，中でも，配合設

表-7 最適アスファルト量の設定

\begin{tabular}{|c|c|c|c|c|c|}
\hline & \multirow{2}{*}{$\begin{array}{l}\text { 再生骨材 } \\
\text { 配合割合 }\end{array}$} & \multicolumn{2}{|c|}{$\begin{array}{c}\text { 各試験から求めた } \\
\text { アスファル量\% }\end{array}$} & \multirow{2}{*}{$\begin{array}{l}\text { 最適アスファ } \\
\text { N量(\%) }\end{array}$} & \multirow{2}{*}{$\begin{array}{c}\text { アスフアル内内訳(\%) } \\
\text { 新 As+旧 As+添加剂 } \\
\text { or 新 As+旧 As }\end{array}$} \\
\hline & & $\begin{array}{c}\text { 付着試験 } \\
\text { (変曲点 } \\
\text { から }\end{array}$ & $\begin{array}{c}\text { 低温㶤 } \\
\text { ブ変曲 } \\
\text { 点から }\end{array}$ & & \\
\hline \multirow{2}{*}{ 配合設計 A } & $30 \%$ & 4.6 & 4.9 & 4.9 & $3.84+0.98+0.08$ \\
\hline & $50 \%$ & 5.1 & 5.3 & 5.3 & $3.31+1.64+0.35$ \\
\hline 配合設計 B & $50 \%$ & - & - & 5.2 & $3.56+1.64$ \\
\hline 配合設計 C & $0 \%$ & 4.8 & - & 4.8 & - \\
\hline
\end{tabular}

表-8＼cjkstart再生ポーラスアスファルト混合物の主な性状

\begin{tabular}{|c|c|c|c|c|c|c|}
\hline & 項 & & $\begin{array}{l}\text { A己合設許 } \\
A<30 \%>\end{array}$ & $\begin{array}{l}\text { 配合設計 } \\
A<50 \%>\end{array}$ & $\begin{array}{l}\text { 配合設訊 } \\
\mathrm{B}<50 \%>\end{array}$ & $\begin{array}{l}\text { 配合設評 } \\
\mathrm{C}<0 \%>\end{array}$ \\
\hline \multicolumn{3}{|c|}{ 安定度 $(\mathrm{kN})$} & 6.43 & 5.5 & 5.41 & 8.71 \\
\hline \multicolumn{3}{|c|}{ フロー值 $(1 / 100 \mathrm{~cm})$} & 58 & 59.3 & 70.1 & 71.7 \\
\hline \multirow{2}{*}{\multicolumn{2}{|c|}{ カンタブロ損失率(\%) }} & $<20^{\circ} \mathrm{C}>$ & 5.1 & 4.1 & 8 & 2.3 \\
\hline & & $<-20^{\circ} \mathrm{C}>$ & 13.7 & 14.4 & 26.8 & 12.3 \\
\hline \multirow{4}{*}{ 圧裂試験 } & 压裂強度(MPa) & $<20^{\circ} \mathrm{C}>$ & 3.34 & 2.69 & 2.46 & 3.8 \\
\hline & $\sqrt{\text { 圧裂変位量 }(\mathrm{cm})}$ & $<20^{\circ} \mathrm{C}>$ & 0.22 & 0.24 & 0.13 & 0.29 \\
\hline & 压裂強度(MPa) & $<60^{\circ} \mathrm{C}>$ & 0.0793 & 0.0599 & 0.0484 & 0.1042 \\
\hline & 圧裂変位量 $(\mathrm{cm})$ & $<60^{\circ} \mathrm{C}>$ & 0.3 & 0.2 & 0.25 & 0.38 \\
\hline \multicolumn{2}{|c|}{ 動的安定度(回/mm) } & $<60^{\circ} \mathrm{C}>$ & 5727 & 3521 & 3901 & 6867 \\
\hline \multicolumn{2}{|c|}{ 据え切り試験（回） } & $<60^{\circ} \mathrm{C}>$ & 1002 & 600 & 259 & 1260 \\
\hline \multirow{4}{*}{ 回収バインタ } & 針入度 $(1 / 10 \mathrm{~mm})$ & $<25^{\circ} \mathrm{C}>$ & 67 & 75 & 61 & 82 \\
\hline & 軟化点 $\left({ }^{\circ} \mathrm{C}\right)$ & & 88.3 & 86.5 & 82.9 & 88.6 \\
\hline & 伸度 $(\mathrm{cm})$ & $<5^{\circ} \mathrm{C}>$ & 76 & 63 & 33 & 70 \\
\hline & $\mathrm{G}^{*} / \sin \delta(\mathrm{Pa})$ & $<60^{\circ} \mathrm{C}>$ & 9840 & 7793 & 7130 & 11102 \\
\hline
\end{tabular}




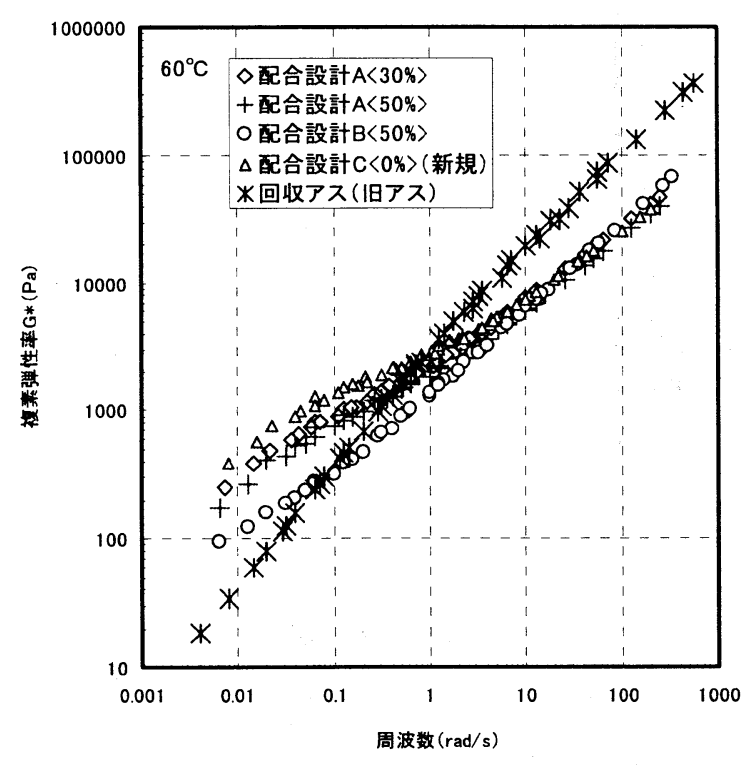

図-9 DSR 試験よる複素弾性率のマスターカーブ

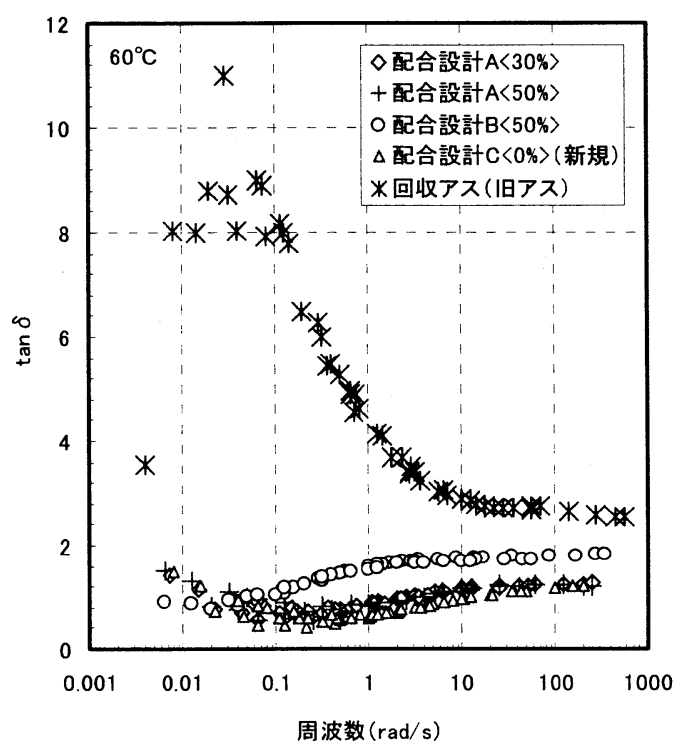

図-10 DSR 試験による $\tan \delta$ のマスターカーブ

訳時に考慮されなかッた高温域 $\left(60^{\circ} \mathrm{C}\right.$ 付近）での性状に ついは，耐久性が劣る可能性を示寸結果となった．従 って, 配合設計時にこれらを補う試験が必要であると考 えられた。

\section{（2）再生バインダの性状}

表-8には，それぞれの混合物から回収したバインダの 主な性状も示した. 針入度では配合設計 B がやや小さい 值を示しているが，高粘度改質アスファルト一般的な下 限值である 40 よりはいずれも大きく特に問題は見られな かった. 軟化点でも高粘度改質アスファルトの一般的な 下限值の 80 を超えており, 特に問題は見られなかった. $5^{\circ} \mathrm{C} に お け る$ 伸度については, 特に一般的な值は示されて いないが，骨材飛散などの破損と関係があるものと考え
られ，值の小さい配合設計 B では，混合物性状への影響 が考えられた. ダイナミック・シア・レオメータ (DSR) 試験の結果は, 而流動性と相関が高いとされている G*/sin $\delta$ で示しているが, 配合割合 $50 \%$ のもの゙比較的值が小 さく, 而久性の面で同等ではない可能性が考えられた.

DSR 試験では，載荷の周波数と測定温度を変え測定す ることにより，その材料特有のマスターカーブが比較的 容易に作成できる，そこで，回収バインダの DSR 試験か ら, バインダの複素弾性率および $\tan \delta$ でマスターカーブ を作成した．結果を図- 9,10 に示す．ここで，横軸が周 波数となっているが，横軸を温度にした場合でも同じよ うな形状の図になることが知られているが，この場合は 左右は逆になり, 右側を低温時, 左側を高温時とした場 合に同じよう形状の図になる. なお, 複素弹性率 G*は弾 性率の一種である. また, $\tan \delta$ はひずみと応力に発生す る位相のずれを位相角 $\delta$ を用いて表現したものであり， 弾性的なものほど0に近づき, 粘性的なものほど大きく なる.

図-9より，まず特徵的なのは，再生骨材に付着してい た旧アスファルトの性状である. 旧アスファルトの複素 弾性率は, 他のバインダと比べた場合, 低温側に相当す る図の右側で大きく，高温側に相当する図の左側で小さ い. また, 改質アスファルトのマスターカーブでは, 通 常変曲点を示すことが多いが，この旧アスファルトでは， 変曲点らしきところがない.さらに, 図-10より $\tan \delta$ は, 図の左に行くほど大きくなっており，粘性体に近づいて いる. これらのマスターカーブの形状は，数值の大小は あるものの，ストレートアスファルトの場合に得られる 形状に比較的似ている.このような旧アスファルトの特 徵は, 劣化によるものと考えられ, アスファルト成分の 劣化により硬化したため図-9 の右側（低温側）でみられ たように複素弾性率が大きくなったものと考えられた.

また，改質材の劣化により，改質材としての働きが弱く なり，図-10のように $\tan \delta$ が左に行く（高温側）と大き くなり，粘性的な傾向を示したものと考えられた。

次に, 再生したバインダである配合設計 AおよびB と， 新規のバインダは配合設計 C を比較する. 配合設計 A で は, 図-9 の右側で新規の配合設計 $\mathrm{C}<0 \%>$ に近い值を示し ているため, 低温側では新規混合物と同等の再生が行え たと見られる. 配合設計 $\mathrm{A}<50 \%>$ と配合設計 $\mathrm{A}<30 \%>0$ 比較では，50\%の方が全体的に小さい值を示し，特に図 の左側で新規のものと差が大きくなっていることから， 高温での性状が若干劣るものと考えられた. 配合設計 B $<50 \%>$ では，図-9，10 ともに新規のものと大きく異な る挙動を示した. 複素弾性率 G*では, 図-9 の左側で新規 のものと比べて小さい值を示し, 高温性状が劣るものと 考えられた. $\tan \delta$ は, 全体的に異なっているが, 特に図 -10 の右側で大きく, 低温性状が異なるものと考えられた. 


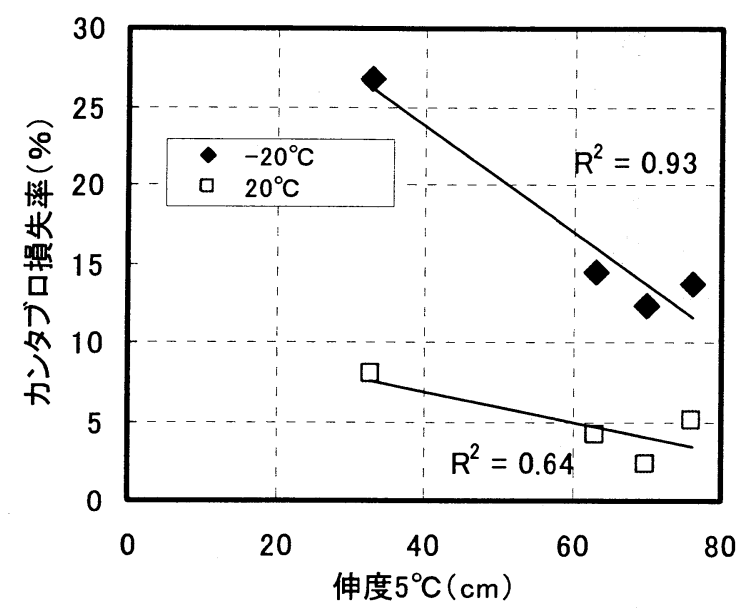

図-11 伸度とカンタブロ損失率

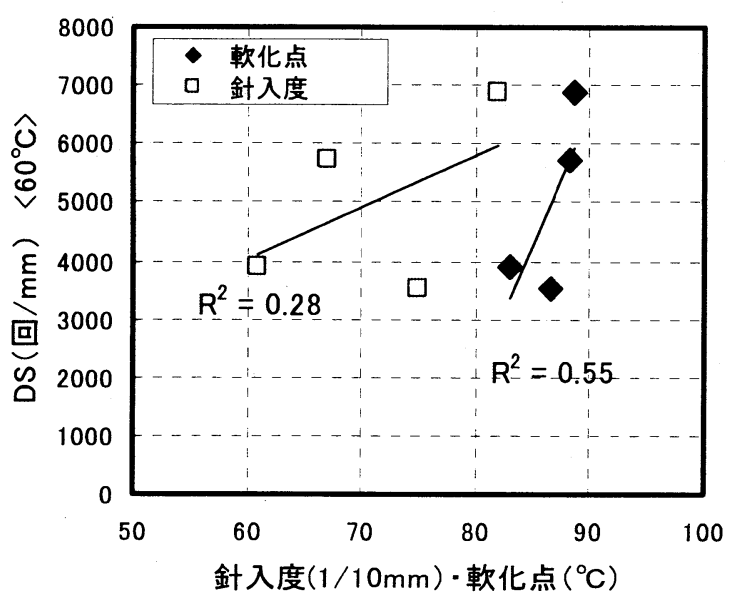

図-12 針入度および軟化点と動的安定度

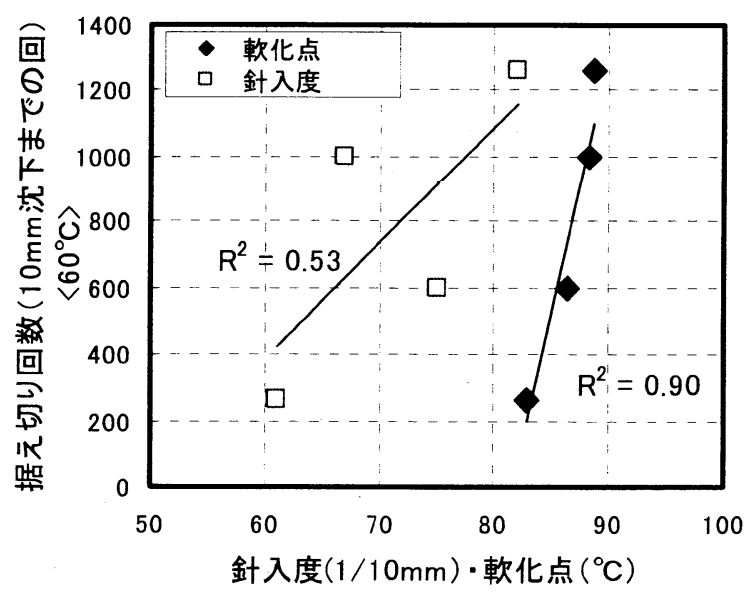

図-13 針入度およひ漸化点と据え切り回数

\section{5. 再生ポーラスアスファルト混合物の配合設計 方法の改善に向けた検討}

4.の結果より，3，で配合設計されたものは，新規 混合物と比へ，高温域 $\left(60^{\circ} \mathrm{C}\right.$ 付近）などで異なる性状が 見られることが分かった．特に配合設計 Bでは，著しく

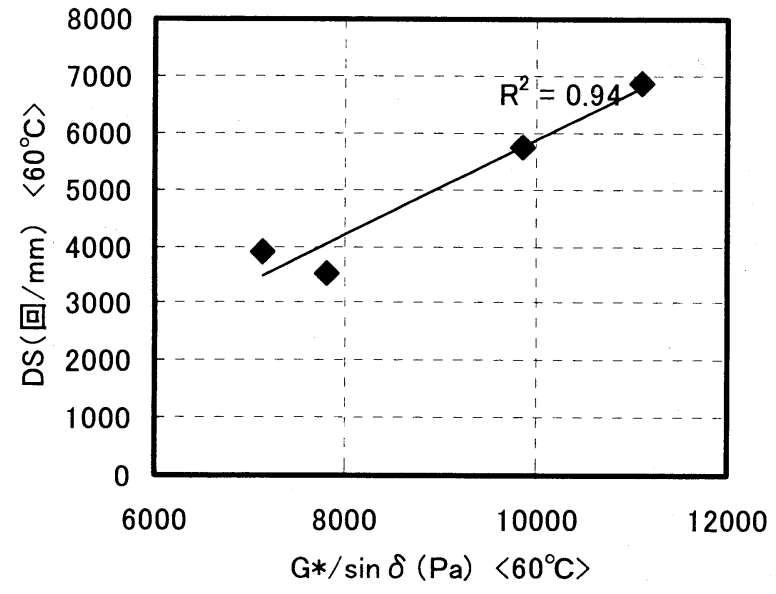

図-14 DSR と動的安定度

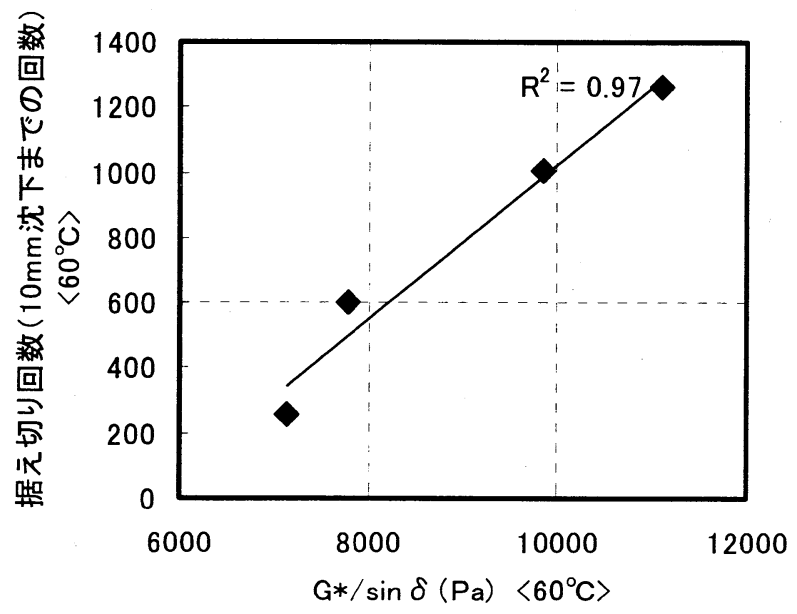

図-15 DSR 試験と据え切り回数

性状が異なっており，配合設計時に新規混合物との性状 比較の段階がないことが影響していると考えられた．従 って, 再生ポーラスアスファルト混合物の配合設計には 新規混合物と同等であることを確保するために高温域で の試験が必要であると考えられた．抽出回収したアスフ アルトの性状を従来のように様々な温度域で細かくチェ ックすることでも可能であるが，抽出回収による性状変 化の問題があり，また時間を要するため, 実用性が低い.

そこで，まずバインダ性状と混合物性状の比較を行い， 関係を把握し，続いてより簡便な混合物試験方法による 代替について検討した。

（1）バインダ性状と混合物性状の比較

バインダ性状試験としては，低温性状として $5^{\circ} \mathrm{C}$ 伸度, 常温性状として針入度，高温性状として軟化点および $60^{\circ} \mathrm{C}$ でのDSR 試験を取り上げ混合物性状との比較を行っ た.

伸度とカンタブロ損失率の関係を見たところ，図-11 に示すとおり，高い相関関係を示した。特に低温での力 ンタブロ損失率とは, 高い相関係数を示した. これより, 従来からバインダの試験項目として重要視されてきた伸 
度は，カンタブロ試験を実施することにより，代用でき る可能性があることがわかった。

次に針入度およひ軟化点と動的安定度 DS およひ据え 切り試験の $10 \mathrm{~mm}$ 沈下までの回数の関係を図-12,13 に示 す。いずれの図でも，針入度は相関が低く，試験温度の 違いも影響したものと考えられたが，軟化点は比較的相 関が高く, 特に据え切り試験との相関が高くなった.さ らに，DSR 試験と動的安定度およひ据え切り回数の関係 を図-14, 15 に示寸。密粒度系混合物で動的安定度との相 関が認められている ${ }^{3)} \mathrm{G}^{*} / \sin \delta$ は，ポーラスアスファルト 混合物でも相関が非常に高くなった．また，据え切り回 数との相関係数は非常に高くなり, 抽出回収でバインダ 試験が行えなくても，これらの試験でも代替可能と考え られた。

しかし，ホイールトラッキング試験や据え切り試験で は, 供試体作製のための試料量を多く必要とし, 特に据 え切り試験では試験機の仕様, 評価方法が定まっておら ず，試験機台数も少ないため，配合設計に利用するには 障害が多いものと考えられる，そこで，さらに簡便な混 合物試験との関係を検討した。

\section{（2）圧裂試験の配合設計用試験への適用性の検討}

配合設計に用いる試験機は，汎用的な試験機で比較的 簡便に行えるものである必要がある. また，4. で示さ れたように, 高温域 $\left(60^{\circ} \mathrm{C}\right.$ 付近)での性状確認が必要である ので, 高温域での試験が可能なことも必要条件である. ここでは，その一つの選択肢として，圧裂試験（舗装試 験法便覧）を実施して, 可能性を検討した. 比較検討は, 軟化点や $\mathrm{G}^{*} / \mathrm{sin} \delta\left(60^{\circ} \mathrm{C}\right)$ と相関の見られた据え切り試 験，伸度と相関の見られたカンタブロ試験について行っ た. なお，本検討では，前述した再生ポーラスアスファ ルト混合物に，製造メーカの異なる改質アスファルトII 型 3 種, 高粘度改質アスファルト 3 種によるポーラスア スファルト混合物も追加した。

図 16,17 に厌裂試験之据元切り圾験の比較を行ったも のを示す．いずれの試験も試験温度は $60^{\circ} \mathrm{C}$ とた．圧裂 変位量よりも圧裂強度の方が相関性が高くなった. デー タは少ないものの, 改質アスファルトI型をバインダに 用いたポーラスアスファルト混合物や据え切り回数が低 かった配合設計 $\mathrm{B}<50 \%>$ (最も左のプロット) などが図 の左下付近に位置しており，これらを排䣄するような目 標設定をして配合設計することで，高温での耐久性に考 慮した再生ポーラスアスファルト混合物の配合設計が行 えるものと考えられた.

カンタブロ試験と圧裂試験の関係について図-18 に示 す.いずれの試験も試験温度は $20^{\circ} \mathrm{C}$ とた. カンタブロ 損失率と圧裂変位量の間にも, 相関関係が見られたが, 図に示した圧裂強度/圧裂変位量が比較的相関関係が高く

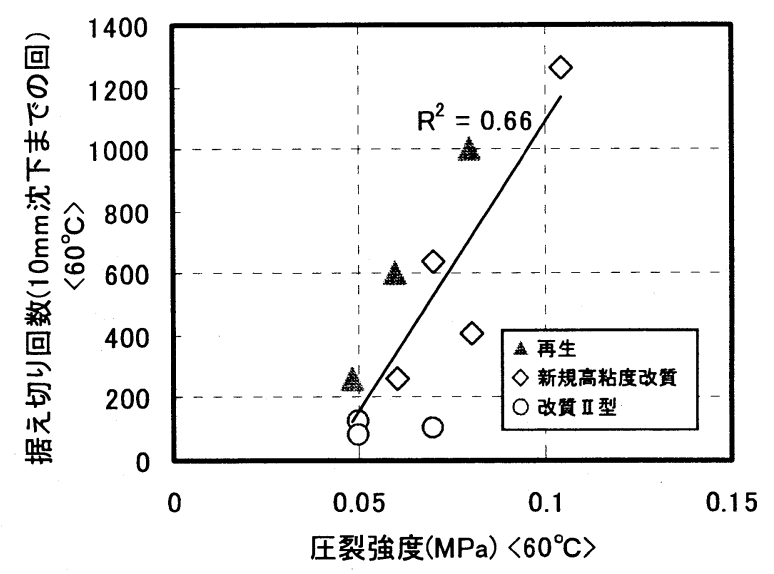

図-16 圧裂強度と据え切り回数

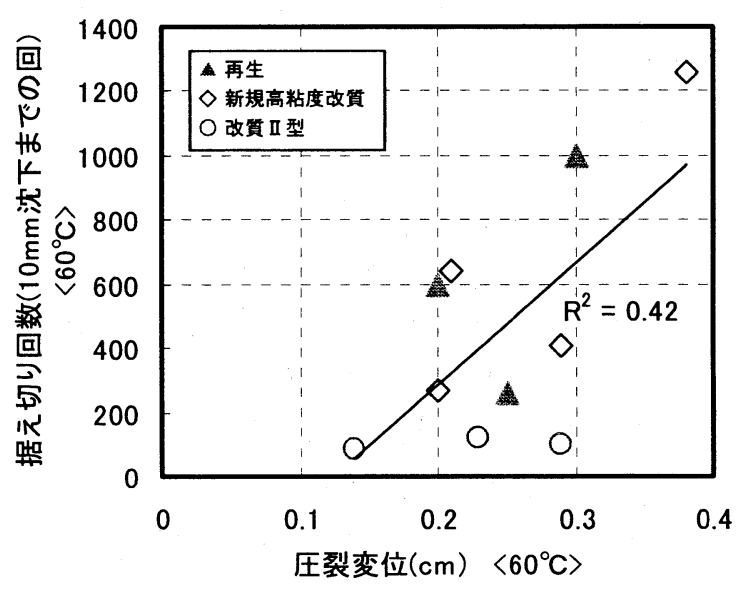

図-17 圧裂変位と据え切り回数

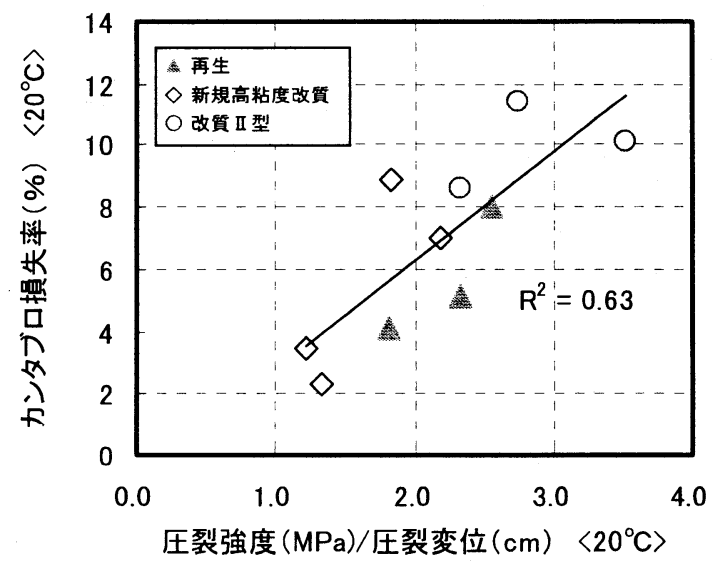

図-18 圧裂試験とカンタブロ試験の関係

なった. カンタブロ試験については, 既に再生ポーラス アスファルト混合物の配合設計に用いる方法が提案され

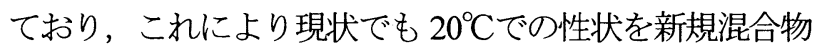
の性状に近くさせることは本研究の中でも確認されてい る. しかし，ここで示したカンタブロ試験と圧裂試験の 関係から $20^{\circ} \mathrm{C}$ 付近の混合物性状評価を圧裂試験に代替寸 ることも可能と見られるため, 配合設計を行う試験機器 等の都合により選択できるようになるものと考えられた. 


\section{6. まとめ}

本研究では, ポーラスアスファルト混合物の再生手法

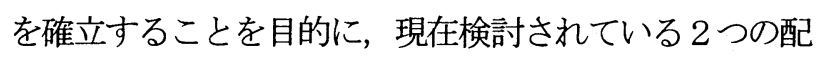
合設計法を用いて再生混合物を作製し，配合設計に関す る課題と諸性状を調査した. さらに, その結果より改善 策について検討した. その結果, 以下のことが分かった.

(a) 舗装再生便覧に紹介された再生ポーラスアスファル 卜混合物の配合設計法における再生用添加剂量の決 定方法や最適アスファルト量の決定方法には若干の 課題が見られた．再生用添加剤量の決定方法では， 今回のように寒冷地仕様のポーラスアスファルト混 合物を目標にすると添加量が求まらないこともある ため, 工夫が必要であると考えられた. また最適ア スファルト量の決定方法では, 現在のダレ試験によ る方法では決定しにくい場合があり他の方法の検討 が必要であると考えられた。

(b) 今回用いた配合設計法による再生ポーラスアスファ ルト混合物の性状を検討した結果，据え切り試験な ど $60^{\circ} \mathrm{C} て ゙$ 行った性状試験の結果が新規混合物と同等 になっていないものもあった. このため, 配合設計 時であまり検討されなかった高温域 $\left(60^{\circ} \mathrm{C}\right)$ におい て，耐久性が劣る可能性があることが分かり，配合 設計時にそれらの温度域での性状を把握する必要が あることが分かった。

(c) 今回用いた配合設計法による再生ポーラスアスファ ルト混合物から抽出回収したバインダの性状を検討 した結果，混合物で見られた傾向と同様に，高温域 での性状が新規バインダの性状と異なり，特に配合 設計時に耐久性に関わる項目をほとんど検討しない 配合設計 B からの再生バインダは，新規バインダと 著しく異なる傾向が見られた. （d）バインダ性状とポーラスアスファルト混合物の性状 比較を行った結果, バインダの一般的な指標である 伸度や軟化点および而流動性との関係が指摘される DSR 試験は, カンタブロ損失率や据え切り回数, 動 的安定度と相関性が見られた。これより, バインダ の抽出回収によらずに，混合物の評価によりバイン ダの回復程度を決めることができるものと考えられ た.

(e) 圧裂試験の配合設計用試験としての適用性を検討し た結果，圧裂試験により高温性状の評価がある程度 可能なことが分かり，圧裂試験を今回用いた配合設 計法に追加することで，高温性状を考慮した配合設 計が行える可能性があることが分かった．また，圧 裂試験とカンタブロ試験の間にも関係が見られたこ とから, 場合によっては, 常温や低温におけるカン タブロ試験も圧裂試験に変更して, 圧裂試験のみで 配合設計が行える可能性があることが分かった.

今後は，圧裂試験を追加した方法での配合設計の実施 による性状改善効果の確認, 混合物での規定值の検討, さらに簡便で確実な配合設計法の検討などを進め, 再生 ポーラスアスファルトの配合設計法の確立を行っていき たい.

\section{参考文献}

1) 新田弘之，伊藤正秀 : 改質アスファルトのリサイクル技術 に関する検討，土木技術資料，vol.46，vol.1，pp.44-49，2004.

2）本松資朗，小澤光一，高橋光彦，向後憲一: 高機能舗装の プラント再生に関する㭘討, 舗装, vol.38, No.7, pp.3-8, 2003.

3）新田弘之，佐々木厳，塚越徹，遠西智次，片脇清：供用性 を重視したアスアア怰験に関する 2,3 の考察，舖装，vol.29， No.8, pp.3-7, 1994.

\section{A STUDY ON MIX DESIGN AND VARIOUS PROPERTIES OF RECYCLED POROUS ASPHALT MIXTURE}

\section{Hiroyuki NITTA, Itaru NISHIZAKI, Akihiro KONAGAI and Masahide ITO}

In this research, to establish the method of recycling porous asphalt mixture, the propriety of two mixing design methods being proposed was examined. The result is shown below. 1) The problem was found in the deciding method of the amount of rejuvenators of recycled porous asphalt mixture and the deciding method of optimal asphalt content. 2) It has been understood might not obtain satisfactory properties about mixture properties not so examined when mixing is designed. 3) It has been understood that there is a possibility to be improved from present methods by adding easy tests. 